\title{
MICROWAVE SOLIDIFICATION DEVELOPMENT FOR ROCKY FLATS WASTE
}

\author{
RFP-4983
}

APRIL 1994

\author{
Prepared By: \\ Dana Dixon, Robert Erle, Veryl Eschen, Gregory Fenner, \\ Ronald Nieweg, and Gregory Sprenger
}

\author{
Technology Development, Residue Treatment Technology \\ EG\&G Rocky Flats, Inc. \\ P.O. Box 464, Building 750 \\ Golden, CO 80402-0464
}

\section{DISCLAIMER}

This report was prepared as an account of work sponsored by an agency of the United States Government. Neither the United States Government nor any agency thereof, nor any of their employees, makes any warranty, express or implied, or assumes any legal liability or responsibility for the accuracy, completeness, or usefulness of any information, apparatus, product, or process disclosed, or represents that its use would not infringe privately owned rights. Reference herein to any specific commercial product, process, or service by trade name, trademark, manufacturer, or otherwise does not necessarily constitute or imply its endorsement, recommendation, or favoring by the United States Government or any agency thereof. The views and opinions of authors expressed herein do not necessarily state or reflect those of the United States Government or any agency thereof.

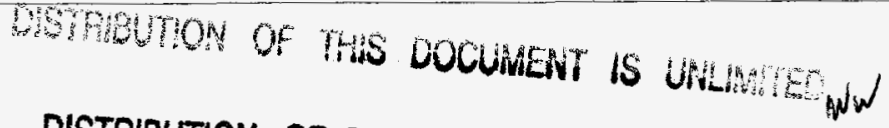

DISTRIBUTION OF TMIS MAMIRICNT IS INUMMTED
} 


\section{DISCLAIMER}

Portions of this document may be illegible in electronic image products. Images are produced from the best available original document. 
Dana Dixon, Robert Erle, Veryl Eschen, Gregory Fenner, Ronald Nieweg, and Gregory Sprenger

Technology Development, Residue Treatment Technology EG\&G-Rocky Flats, Inc.

P.O. Box 464 , Building 750

Golden, CO 80402-0464

\begin{abstract}
The Microwave Engineering Team at the Rocky Flats Plant has developed a production-scale system for the treatment of hazardous, radioactive, and mixed wastes using microwave energy. The system produces a vitreous final form which meets the acceptance criteria for shipment and disposal. The technology also has potential for application on various other waste streams from the public and private sectors. Technology transfer opportunities are being identified and pursued for commercialization of the microwave solidification technology.
\end{abstract}

\title{
INTRODUCTION
}

\section{Historical and Regulatory Perspective--}

As a major production facility in the Department of Energy's (DOE) nuclear weapons complex, the Rocky Flats Plant (RFP) near Golden, Colorado fabricated a variety of fissile and non-fissile components during its forty years of supporting national defense requirements. While operating to execute its mission, the plant generated, treated, stored, and disposed of various waste streams, including radioactive, hazardous, and mixed wastes. Until a few years ago, these wastes were disposed of by shallow burial at DOE owned facilities. These operations were conducted in accordance with the rules for storage and disposal set forth by the Nuclear Regulatory Commission. At that time, it was DOE's position that this approach was sufficient for the management of these wastes and that Resource Conservation and Recovery Act (RCRA) standards for land disposal did not apply. This posture was reinforced by DOE's attitude that federal sovereign immunity precluded court actions to force compliance. As it turned out, this may have been a naive attitude. 
In 1989 plant operations were curtailed due to these issues surrounding DOE's compliance with RCRA regulation. At that time, DOE's waste management philosophy was challenged in the courts by several organizations. The resulting decisions and court orders mandated that DOE comply with the federal RCRA standards for land disposal. Additionally, moratoriums and restrictions imposed at DOE owned waste disposal sites prevented the shipment and disposal of waste from RFP. This situation, compounded by the dramatic change in the world political climate, forced a change in the plant's mission from one of supporting weapons production to that of waste management and environmental restoration.

The : Drivers--

At this time, a number of these wastes are still being generated in small volumes. This is a result of operations to maintain vital safety systems and to accommodate the new plant mission. Unfortunately, due to hazardous characteristics, not all of the legacy and newly generated wastes meet the RCRA requirements and are restricted from land disposal without treatment Additionally, RFP was not designed nor intended for long-term storage of waste materials. Many areas currently being used for waste storage do not meet RCRA storage requirements. The bottomline is that RFP is out of compliance with the RCRA regulations for storage and disposal of hazardous wastes.

The Solution--

After operations were curtailed in 1989, a major effort was initiated to bring the plant into compliance. The first order of business was the negotiation of a Federal Facilities compliance Agreement (FFC Agreement) between the state of colorado, the Environmental Protection Agency, DOE, and EG\&G, Rocky Flats. This agreement set forth a preliminary road-map for achieving compliance at RFP. It required the generation of a series of treatment plans and reports that thoroughly examined the waste issues and possible technological solutions to the treatment needs. In the plans and reports numerous technologies were identified and reviewed for application at RFP.

Since the initial plan and reports were prepared, the FFCA and the compliance road-map has been subject to several modifications and refinements. However, the original goal of ultimate compliance with the RCRA regulations has been doggedly pursued. To meet this end, efforts toward development and implementation of several waste treatment technologies continue. One technology that is particularly new and innovative utilizes microwave energy to heat, melt, and vitrify a variety of inorganic waste streams. The final waste form produced by microwave solidification is a glass or mineral-like monolith that does not contain free-liquid or releasable particulates, and is highly leach resistant. It is 
extremely robust and is especially suited for hazardous and mixed wastes. The microwave solidified waste form meets all criteria for shipment and disposal at either the Nevada Test site (NTS) or the Waste Isolation Pilot Plant (WIPP). Vitrification is also attractive from a life-cycle cost perspective due to the significant waste volume reductions that are possible, up to $97 \%(1,2)$. It has been recognized as a waste form that potentially has the widest applicability to waste treatment and is being considered by the Mixed Waste Integrated Program as the enhanced waste form(3).

\section{A Specific Rocky Flats Plant Problem--.}

The generation of nearly 1,200 cubic feet per year, coupled with a backlog inventory of 18,000 cabic feet, makes precipitation sludge one of the largest waste streams at RFP. This sludge is generated when liquid effluent from throughout the plant (process solutions, laundry effluent, precipitation run-off, sump liquid from building footer drains, etc.) are cleaned and polished before final disposition in a multi-effect evaporator. Radioactive and heavy metal components contained in the liquid effluent are removed during a hydroxide coprecipitation process. As the insoluble sludge is precipitated and falls through the solution, it coagulates the materials to be removed which is collected at the bottom of a settling tank.

The current treatment of this waste material is accomplished by cement stabilization using diatomite and Portland cement.

Cementation is not an optimal treatment technology for this waste stream; it produces significant volume increases in the final waste form. This situation increases disposal costs (which is determined by waste volume) and puts a significant burden on the disposal facilities (obviously finite in capacity).

Additionally, the products of cementation are highly sensitive to characteristics of the waste stream. Small amounts of so-called poisons can upset the process destroying the quality of the product. This leads to two situations, (1) either the process parameters must be overly conservative, or (2) the process is highly controlled based upon the feed stream characterization. Microwave solidification was-identified as a potential replacement for cement stabilization and was selected for utilization on a variety of inorganic wastes.

In addition to the hydroxide coprecipitation sludges currently under investigation, several other waste streams have been identified as potentially amenable to microwave solidification. These wastes include incinerator ash, nitrate salts, solar pond sludge, remediation soils, asbestos, and materials from foundry operations. Potential for application of this treatment technology also exists at other DOE facilities. For example, Los Alamos National Laboratory treats Iiquid effluent from its 
research and laboratory facilities with a similar coprecipitation process. Buried and legacy wastes at Hanford, Idaho National Engineering Laboratory, and Oak Ridge National Laboratory could be processed through the microwave solidification technology. Transfer of the technology to the facilities and to private enterprise will be pursued through the implementation of a technology transfer strategy and action plan.

\section{Additional Requirements--}

Compounding any effort to develop a technology for treating mixed wastes is the fact that additional regulatory requirements must be met. In addition to the land disposal restrictions imposed by RCRA, the technology must also satisfy Department of Transportation requirements for the packaging and shipment of the waste and the waste acceptance criteria at the disposal facility, either NTS or WIPP. This set of restrictions leads to a complicated effort when developing an integrated treatment facility. However, the robustness of a vitrified product coupled with the simplicity of microwave melting allows this process to meet the various requirements with minimal effort.

\section{MICROMAVE SOLIDIFICATION}

Project History--

The Microwave Solidification Development effort finds its roots in a research project that was initiated in 1985. At that time, the Waste operations group was experiencing difficulty obtaining a certifiable waste product from the cement stabilization process. The product contained free liquids that are prohibited by DOT and RCRA regulations. Waste operations sponsored a research and development (R\&D) effort to select an appropriate drying methods for implementation in the process. A small group of $R \& D$ engineers were assigned to the task. They decided to test a standard microwave dryer design which was used in the food processing industry for pasta drying and precooked food

preparation. As the development project progressed, the R\&D team discovered that the process had potential beyond that of mere drying. In fact, temperatures could be achieved that were high enough to actually melt the waste forming a vitreous product. This was a substantial achievement for it opened the door for significantly improving the waste form.

In order to fully evaluate the technology, several systems were deployed at RFP ranging in size from bench, pilot, and full-scale systems. The results indicate that the technology is easily scaled which provides flexibility for selecting a system for a specific application. To facilitate advanced studies and design of an implementable production system, a fully integrated, self- 
directed engineering team has been assigned to the R\&D program. The microwave engineering team (MET) has been built to achieve maximum efficiency and success by incorporating all necessary engineering disciplines, including mechanical, design, electrical, microwave, chemical, metallurgical, and nuclear(4). The focus of the program is to develop a complete waste treatment system which incorporates all necessary ancillary systems into a process configuration:- To ensure successful implementation in a radiologically controlled environment, the reliability, accessibility, availability, and maintainability (RAAM) characteristics of the system is being evaluated. This information will be used.to.finalize_to the equipment design and layout for a production installation.

\section{Process Description--}

The feed preparation sequence is critical in the RFP design and as such it has received a great deal of attention. This aspect of the process impacts a series of down-stream equipment selections and operating parameters. The process equipment must be contained in a glovebox to prevent release of radiological contaminants into the work environment. This requirement severely limits access for normal maintenance and housekeeping activities. Dust is a major concern and equipment has been selected to reduce its generation in the glovebox during operation. Additionally, it virtually eliminates any possibility of altering equipment to meet process needs as the waste stream changes. Therefore, the feed preparation equipment must be flexible in application and robust in operation.

The MET has selected a feed preparation configuration that incorporates a break open system to recover inventoried legacy waste from storage drums, a ball-mill, a granulator, and a multiple tray direct dryer. The ball-mill is a versatile piece of equipment that has many attractive features. It is capable of size reduction and mixing while accepting wet or dry feed. In the ball-mill, glass formers are added to produce a waste loading of approximately 50\%. A pan agglomerator was evaluated, but the MET felt that it was difficult to operate and clean after use (5). As a result, a granulator which uses roll. compaction to eliminate free particulate is being considered. The dryer was selected due to previous applications in the nuclear industry and for the gentle handling of the waste during its operation. After drying, the feed material is placed in a surge hopper for accumulation before melting.

To initiate the melting process, a 30 gallon drum is placed in an insulation cage and lifted into position using a rotating lifttable. In this configuration the drum has been connected to the microwave applicator via a rotary choke assembly. A small amount of waste material is transferred from the surge hopper to the 
drum through a screw conveyor. Microwave energy is transmitted from a 60 kilowatt, 915 megahertz generator to the 30 gallon drum which raises the temperature of the waste material to approximately 1000 degrees centigrade causing it to melt. After the initial charge has been melted, continuous feed of the remaining waste material begins. The process continues until 320 kilograms of waste has been melted. At this time, the microwave transmission is interrupted and the drum is removed from the insulation cage and transferred to a cool down/inspection station. While still molten, the product is sampled for analytical characterization and certification. The drum is allowed to cool and solidify before being removed from the glovebox using a bagless posting system.

Effluent gases are removed from the processing chamber by a downstream blower system. The composition of the effluent is monitored using a fourier transform infrared spectrometer. suspended particulates are removed by passing the gas stream through a high efficiency cyclone and a sintered metal high efficiency particulate (HEPA) filter. Oxides of nitrogen and sulfur are produced during the operation by the thermal decomposition of nitrates and sulfates in the waste feed material. These components are removed from the effluent gas using a granulated activated carbon filter. This system was selected because of its low maintenance requirements, ease of operation, broad scavenging capabilities, and limited generation of a secondary waste stream. Finally, the clean effluent is passed through a roughing filter before it enters the building's filter plenum where it is polished through several stages of HEPA filtration. The possibility of actinide volatility during waste vitrification was examined at Lawrence Livermore National Laboratory (6). Their test work indicated that a conservative estimate of the vapor pressure of plutonium oxyhydroxide above the melt would be on the order of $8.2 \times 10^{-14}$ atmospheres. This is a negligible quantity and poses no risk to the environment or public.

\section{Advantages--}

The process developed at RFP is an in-drum melting system designed to isolate the waste material in a shipping container during the process. Several advantages to the microwave solidification process have been identified through the development program.

- Most significant is the tremendous waste volume reduction that is realized by the process. As stated earlier, up to 97\% volume reductions have been observed. This characteristic favorably impacts the life-cycle costs for the process and relieves storage limitations at the final waste interment facility.

- Due to its vitreous nature, the solidified waste product 
offers a leach resistant, stable matrix especially suited for hazardous and radioactive waste: it will meet all applicable waste acceptance criteria at the disposal Facility.

- The equipment is inexpensive and easy to maintain because the heat is contained in the disposal drum which is insulated from the rest of the process equipment.

- Greater energy. transfer efficiency is achieved due to direct coupling between the microwave energy and the waste material.

- Since the waste is being heated directly, energy control is instantaneous... The process can be brought to operational temperature in a matter of minutes, compared to competing thermal processes which can take hours.

- Because the material is being processed in-drum, it does not have to flow from a melting crucible to a shipping container. This eliminates viscosity concerns allowing much higher waste loading and product density.

Status of Development--

Since the beginning of the R\&D program in 1985, numerous studies have been conducted in bench, pilot, and full-scale demonstration systems at RFP. A majority of this work was completed using a non-radioactive, non-hazardous surrogate that represented the bulk chemical and physical properties of the hydroxide coprecipitation sludge. These studies were focused at obtaining information for preliminary recipe formulation, selection of operating parameters, equipment specification, and economic analysis of the process (7).

In 1993, a series of bench-scale experiments were conducted using a non-radioactive, spiked surrogate material(8). The objective of these studies was to identify the critical operating parameters for the process. Several parameters, including waste loading, borax content, temperature, and quench rate, were examined using a statistically designed experimental matrix. After preparing the surrogate and spiking with heavy metals at concentrations expected in the actual waste stream, the samples were melted in the microwave system and the products were subjected to Toxicity Characteristic Leach Procedure (TCLP) analysis. The results of the study indicated that only waste loading and borax content were critical. By eliminating two noncritical variables from the process equation, optimization of the process is greatly simplified. Efforts are currently underway to complete optimization of the operating parameters and the process configuration.

Numerous other scoping studies using the bench-scale systems are underway to determine the full application potential of the technology on a wide variety of newly assigned waste streams. 
These studies will also examine the possibility of combining waste materials to achieve higher waste loads which provides further improvements in the process economics.

In addition, a series of studies were conducted on actual hydroxide sludge from the liquid waste treatment facility(9). The tests achieved a $72 \%$ waste reduction, $2.17 \mathrm{~g} / \mathrm{cc}$ density, and $60 \%$ waste loading: These results were similar to those obtained on the non-radioactive surrogates, thus validating the applicability of the technology on the actual waste material. Further studies on the actual hydroxide sludge are underway to confirm TCLP performance of the product.

The feasibility of production implementation of the microwave solidification process has been proven using a full-scale demonstration system. This system has been in operation since 1989. The test results from this facility indicate that the technology can be easily scaled from bench to production operations. Final form densities of up to $3.0 \mathrm{~g} / \mathrm{cc}$ were obtained and the products passed TCLP analysis. Waste loading levels of $60 \%$ were easily achieved and may be pushed to as high as $100 \%$ by combining waste streams to achieve appropriate glass formulations. One possibility that has received a great deal of attention is the use of spent raschig rings from solution storage tanks as a silica source in the operation. These rings are a high quality borosilicate glass and have proven to be extremely amenable to microwave processing through scoping investigations.

At the current time, the full-scale demonstration system is being used as a test bed for integration of the ancillary systems into a complete production configuration. This evaluation is critical to arriving at the final design package. All aspects of the operation must be fully understood (feed preparation, material handling, product packaging, off-gas monitoring and treatment, as well as the microwave solidification operation) so that no significant design flaws are carried into the production system. Additionally, the wave transmission and control system is being optimized to achieve the highest level of efficiency, product quality, and economic attractiveness possible. These investigations will be complete in June, 1996.

As a result of the tremendous success of the program, production implementation efforts have been initiated. A conceptual design report (CDR) has been submitted to the DOE. The CDR has been successfully reviewed through the justification/validation process. Preparation of the design criteria has begun and implementation of the technology has been designated as a fiscal year 1996 capital project. At that time, the title design phases will be initiated and the process should be brought into full production operations in 1998. 


\section{TECEMOLOGY TRANSFER OPPORTUNITIES}

The success of the demonstration program to date has motivated the MET to identify and pursue the transfer of the technology to other applications. To accomplish this objective, the team has developed a multi-facetted approach for technology transfer to possible customers at RFP, the DOE at large, other public institutions, and private sector industries.

First, the MET recognizes the broad potential of the technology for the treatment of RFP wastes. These opportunities are being pursued through the submittal of treatability study proposals to on-site waste treatment and environmental remediation organizations. Several-significant projects are being formulated, including, the treatment of residues, solar pond sludge, and remediation soils from Operable Unit Number 2 . In addition to the RFP specific treatment applications, there are numerous opportunities for the treatment of other government owned legacy and site remediation wastes. These include the inventoried wastes at Oak Ridge National Laboratory, the buried wastes at the Idaho National Engineering Laboratory, liquid waste treatment sludges from Technical Area 50 at the Los Alamos National Laboratory, and the remediation wastes at the Hanford reservation.

The microwave solidification technology can also be applied to private sector waste materials, including, sludges from steel manufacturing, superfund remediation soils, ash from hazardous waste incinerators, and fly ash from commercial power facilities. The far reaching potential for application of this technology has been acknowledged by the Western Governors Association which selected the technology for participation in the Develop on-site Innovative Technologies (DOIT) program. This will provide an enormous boost for the technology and will accelerate transfer into the private sector. To monopolize on this momentum, the MET has developed a strategy which details actions for transfer of the technology to the private sector. Potential technology transfer participants and customers have been identified and proposals have been submitted for their review. Additionally, memorandums of understanding and technology licensing agreements are being developed in appropriate areas.

\section{SUMMARY}

The microwave solidification technology being developed and optimized at RFP is an excellent process for the treatment of hazardous and/or radioactive wastes. Several advantages have been identified for this technology over currently competing treatment technologies. It produces a product that meets the transportation and disposal criteria and is cost competitive on a 
life-cycle basis. Additionally, microwave solidification has broad application in both the public and private sectors. This opportunity is being pursued through a technology transfer program at RFP.

\section{RETERENCES}

(1) C.M. Jantzen, J.B. Pickett, and W.G. Ramsey, "Reactive Additive stabilization process (RASP) for Hazardous and Mixed Waste Vitrification, Proceedings of the Second International Mixed Waste-Symposium, Baltimore, Maryland, August 1993, U.S. DOE Report WSRC-MS-93-118.

(2) C.M. Jantzen, "Solidification of Consolidated Incinerator Facility (CIF) Wastes in Soda-Lime-Silica (SIS) Glass: Use of Reactive Additives to Retain Hazardous and Heavy Metal Constituents, Savannah River Technology Center, Westinghouse Savannah River Co., Aiken, South Carolina, August 1992, U.S. DOE Report WSRC-TP-92-214.

(3) R.F. Schumacher, C.M. Jantzen, and M.J. Plodinec, "status of Vitrification for DOE Low-Level Mixed Waste, Savannah River Technology Center, Westinghouse Savannah River Co., Aiken, South Carolina, April 1993, U.S. DOE Report WSRC-MS-92-504.

(4) EG\&G Rocky Flats, Inc., Brochure, Microwave Solidification at Rocky Flats: Facilities, systems, and Capabilities, EG\&G Rocky Flats Plant, Technology Development, P.0. Box 464; Golden, Colorado, March 1994.

(5) R.C. Jantzen and G.S. Sprenger, "Feed Preparation and Particulate Testing of the Microwave Solidified Hydroxide Sludge, EG\&G Rocky Flats Plant, Technology Development, P.O. Box 464. Golden, Colorado, October 1993, Internal Publication, GSS-111-93.

(6) O.H. Krikorian, R.H. Condit, A.S. Fontes, Jr., W.F. Morris, J.W. Magana, and R.W. Lougheed, "Study of Plutonium Volatility Under Microwave Melting Conditions Used for Glass Encapsulation of Plutonium Sludge Wastes: Final Report, Lawrence Livermore National Laboratory, Livermore, California, April 1993, U.S. DOE Report UCRL-ID-113718.

(7) R.D. Petersen, A.J. Johnson, and S.D. Swanson, "Application of Microwave Energy for In-Drum Solidification of Simulated Precipitation Sludge, Rockwell International, North American Space Operations, Rocky Flats Plant, P.O. Box 464, Golden, Colorado, August 1987, U.S. DOE Report RFP-4148.

(8) V.G. Eschen, G.S. Fenner, and G.S. Sprenger, "Critical 
Parameters and TCLP Performance of the RFP Microwave solidification system, stabilization and solidification of Hazardous, Radioactive, and Mixed Wastes, ASTM STP 1240, T. Michael Gilliam and Carlton C. Wiles, Eds., American Society for Testing and Materials, Philadelphia, 1994.

(9) R.D. Petersen, "Microwave Vitrification of Rocky Flats TRU Sludge, EG\&G Rocky Flats Plant, P.O. Box 464, Golden, Colorado, 1989, U.S. DOE Report RFP-4414. 